\title{
SCREENING FOR VIRULENCE GENES IN ESCHERICHIA COLI O157:H7 OBTAINED FROM DRINKING WATER FROM IKARA, KADUNA STATE, NIGERIA.
}

\author{
Alalade, O. M. ${ }^{* 1}$, Ameh, J. B. ${ }^{2}$, Abdullahi, I. O. ${ }^{2}$ and Whong, C. M.Z. ${ }^{2}$ \\ *1- Department of Food Science and Technology, Kano University of Science and Technology, PMB 3244, Wudil, \\ Kano State, Nigeria. E-mail: mofolu4real@yahoo.com Tel: 08035790231 \\ 2- Department of Microbiology, Ahmadu Bello University, Zaria, Kaduna State, Nigeria. \\ ameh2070@yahoo.com,08028835625; ioabdullahi@abu.edu.ng,08037033146; \\ clementwhong@yahoo.com, Tel.08093863366 \\ *Corresponding author: E-mail: mofolu4real@yahoo.com Tel: 08035790231 \\ (Received: 31 ${ }^{\text {st }}$ October, 2017; Accepted: $9^{\text {th }}$ February, 2018)
}

\section{ABSTRACT}

\begin{abstract}
Eighty (80) sources of drinking water comprising boreholes (24), streams (3), wells (29), pipe-borne (5) and 19 sachet water samples were collected between March 2014 and February 2015. Escherichia coli (E.coli) O157:H7 was isolated by enrichment in Tryptone soy broth at elevated temperature and streaking on Eosin Methylene Blue agar. Typical green colonies with metallic sheen were Gram stained, after which biochemical tests and streaking on cefuxime-tellurite sorbitol MacConkey agar was done, followed by serological tests and by partial sequencing of the $16 \mathrm{~S}$ rRNA gene were carried out to confirm the identity of the isolates. The isolates were screened for the presence of virulence genes (stx1, stx2, eaeA, hlyA) using the polymerase chain reaction (PCR) technique with specific primers. Three samples ( 2 wells and 1 stream) were found to be contaminated with E. coli O157:H7. None of the isolates possessed the st $x 1$ gene, one carried the eae $A$ gene $(229 \mathrm{bp})$, while all three showed amplicons for the $s t \times 2$ and $b y A$ genes (1181 and 534bp respectively). The $16 \mathrm{~S}$ rRNA sequences were deposited in the National Center for Biotechnology Information GenBank under accession numbers KX602652, KX602653 and KX602654. The isolation of this organism possessing virulence genes from drinking water is of public health significance and therefore, more attention needs to be paid to drinking water of Ikara, Kaduna state.
\end{abstract}

Keywords: Drinking water, Escherichia coli O157:H7, PCR, virulence genes

\section{INTRODUCTION}

In Nigeria, as with other developing countries, there is relative scarcity of potable water that can be used for drinking and other domestic purposes (WHO and UNICEF, 2010). The quality of drinking water is of importance to human health. It has been estimated that about 3.4 million people die due to the effects of water-borne diseases, and children form a large percentage of this figure (UNICEF, 2008). Most bacterial pathogens usually get to drinking water through feacal contamination, either through sewage or other sources of contamination.

Escherichia coli (E. coli) is a normal flora of the gastrointestinal tract of animals and humans. However, some strains such as the O157:H7 strain possess virulence genes such as the intimin gene (eae $A)$, the shiga toxin genes (stx 1 and stx 2 ), haemolysin gene $(b y A)$ among others (Mora et al. 2007). This organism has been associated with intestinal disease such as bloody and non-bloody diarrhea, with complications like haemorrhagic colitis and haemolytic uraemic syndrome which is a life-threatening condition (Kaper et al. 2004). E. coli $\mathrm{O} 157: \mathrm{H} 7$ has been isolated from vegetables, well water, meat, abattoirs, fruits and so on (Franiczek et al. 2006; Tijjani et al. 2006 and Olukosi et al. 2008).

In this report, we examined the prevalence of Escherichia coli $\mathrm{O} 157: \mathrm{H} 7$ in drinking water from Ikara, Kaduna state, Nigeria, and screened the isolates for the presence of some virulence genes.

\section{MATERIALS AND METHODS Study Location}

Ikara is the headquarters of Ikara Local Government Area of Kaduna North senatorial district of Kaduna state in the North-Western part of Nigeria. The town is about $75 \mathrm{~km}$ North-east of Zaria. The people are predominantly of the Hausa and Fulani ethnic groups and the population of the town is about 194,723 people (NPC, 2006). The sources of drinking water available at the time of sampling in the town 
included boreholes and wells mainly, a few areas had pipe-borne water and there were a few streams.

\section{Sample Collection}

The samples were collected randomly, based on availability at the time of sampling which was between March 2014 to February 2015.

The borehole, well, stream and pipe borne water samples were aseptically collected in sterile containers while the sachet water samples were purchased from selling points and were all transported to the laboratory of the Department of Microbiology, Ahmadu Bello University, Zaria in ice boxes for analysis within 6 hours of collection.

\section{Isolation of E. coli O157:H7}

Escherichia coli $\mathrm{O} 157: \mathrm{H7}$ was isolated from the water samples using the method of LeJejune et al (2001). Twenty (20) millilitres of each water sample were inoculated into duplicate flasks containing $20 \mathrm{ml}$ of sterile double strength tryptone soy broth. The tubes were incubated at $44 \bigcirc \mathrm{C}$ for 24 hours. After this time, a loopful of the enrichment culture was streaked on plates of EMB agar and incubated at $44 \bigcirc \mathrm{C}$ for 24 hours. Mixed cultures were re-streaked for purity on plates of sterile EMB agar and then colonies that were observed to be shiny green with dark centres were transferred to nutrient agar slants and Gram stained before storage for further identification.

\section{Biochemical characterization of the isolates}

The presumptive E. coli isolates were subjected to a number of conventional biochemical tests which include indole, citrate, methyl red, VogesProskaeur, motility, Triple sugar iron, and urease tests (Cheesebrough, 2006). The Microgen Enterobacteriaceae GN A ID kit was used for further biochemical characterization of the organisms using the Microgen ID computer software, version 1.2.5.26.

The isolates that were confirmed to be E. coli on the basis of their Gram reaction and biochemical profiles were streaked on cefuxime-tellurite Sorbitol MacConkey agar and incubated at $37^{\circ} \mathrm{C}$ for 18 hours. Those that were sorbitol negative (colourless colonies) were tested with the E. coli O157:H7 latex agglutination kit (Microgen, England) for confirmation of E. coli O157:H7. Those that showed agglutination with the kit were recorded as positive E. coli O157:H7 (Renter et al., 2003).

\section{DNA Extraction}

A single colony of pure culture of each isolate selected for the polymerase chain reactions (PCR) were inoculated into $10 \mathrm{ml}$ of Luria-Bertani (LB) broth medium and incubated at $37^{\circ} \mathrm{C}$ overnight. The overnight culture was streaked on nutrient agar to obtain pure colonies. The colonies were picked into Eppendorf tubes and the cells were lysed in $400 \mu \mathrm{l}$ of lysis buffer. Exactly $40 \mu \mathrm{l}$ of proteinase was added to $200 \mu \mathrm{l}$ of the isolates and mixed. The tubes were incubated at $65^{\circ} \mathrm{C}$ for 10 minutes. After this, $400 \mu \mathrm{l}$ of phenol chloroform was added and the tubes were vortexed to mix. They were centrifuged at $13,000 \mathrm{rpm}$ for 10 minutes, after which the upper layer was pippetted into freshly labelled tubes. To the new tubes, $400 \mu \mathrm{l}$ of chloroform was added and the tubes were vortexed and centrifuged again.

To the upper layer, $1 \mathrm{ml}$ of $100 \%$ ethanol and $40 \mu \mathrm{l}$ of $3 \mathrm{M}$ sodium acetate were added and the tubes were stored at $-20{ }^{\circ} \mathrm{C}$ overnight. After the incubation period, the tubes were centrifuged at -4 ${ }^{\circ} \mathrm{C}$ for 1 hour after which the ethanol was discarded. Then, $400 \mu$ l of $70 \%$ ethanol was added and the tubes were centrifuged at 13,000 rpm for 10 minutes. The ethanol was then discarded and the DNA was air-dried. Then, $50 \mu$ of DNasefree water was added and the DNA was stored at $20^{\circ} \mathrm{C}$ for further use.

\section{Primer design}

The oligonucleotide primer sequences used in this study were as used by various researchers as indicated in table 2.1. They were designed by Inqaba Biotech, South Africa, except the $16 \mathrm{~S}$ rRNA primer which was manufactured by Integrated DNA Technologies, USA. They were all diluted following the manufacturer's instructions to produce working solutions for the PCR (Moyo et al., 2007; Bitrus et al., 2011). 
Table 2. 1: Primers used in this study

\begin{tabular}{|c|c|c|c|c|}
\hline Primer & Primer sequence $\left(5^{\prime}-3^{\prime}\right)$ & $\begin{array}{l}\text { Size } \\
\text { (bp) }\end{array}$ & $\operatorname{Tm}\left({ }^{\circ} \mathrm{C}\right)$ & Reference \\
\hline bly $A$ & $\begin{array}{l}\text { GCA TCA TCA AGC GTA CGT TCC } \\
\text { AAT GAG CCA AGC TGG TTA AGC T }\end{array}$ & 534 & 61.5 & $\begin{array}{l}\text { Paton and } \\
\text { Paton, } \\
(1998)\end{array}$ \\
\hline eae $A$ & $\begin{array}{l}\text { TGA TAA GCT GCA GTC GAA TCC } \\
\text { CTG AAC CAG ATC GTA ACG GC }\end{array}$ & 229 & 61.5 & $\begin{array}{l}\text { Moyo et al., } \\
(2007)\end{array}$ \\
\hline st $x 1$ & $\begin{array}{l}\text { ACA CTG GAT GAT CTC AGT GG } \\
\text { CTG AAT CCC CCT CCA TTA TG }\end{array}$ & 614 & 60.4 & $\begin{array}{l}\text { Jalil et al., } \\
(2011)\end{array}$ \\
\hline st $x 2$ & $\begin{array}{l}\text { ATGAAGTGTATATTATTTAAATGGGTAC } \\
\text { TCACAGATAAAACACTCTCCAGG }\end{array}$ & 1181 & 64.0 & $\begin{array}{l}\text { Ding et } \\
\text { al..(2011) }\end{array}$ \\
\hline 16SrRNA & $\begin{array}{l}\text { AGA GTT TGA TCA TGG CTC AG } \\
\text { AAG GAG GTC ATC CAA CCG CCA }\end{array}$ & 1500 & 56.0 & \\
\hline
\end{tabular}

PCR for the detection of virulence markers stx1, stx2, hlyA, and eaeA genes in the E. coli isolates

Specific primers sets were used to detect Stx1, Stx2, hlyA and eaeA genes in the E. coli O157:H7 isolates in separate PCR reactions. The PCR reaction mixture of $10 \mu \mathrm{l}$ contained $5 \mu \mathrm{l}$ of master mix (Promega, USA), $1 \mu$ l of nuclease free water, 3 $\mu \mathrm{l}$ of template DNA and $0.5 \mu \mathrm{l}$ of each primer mix. A tube containing all the above except the DNA template was also included to serve as a negative control.

PCR amplification included the initial denaturation at $94{ }^{\circ} \mathrm{C}$ for 5 minutes. This was followed by denaturation at $94{ }^{\circ} \mathrm{C}$ for 20 seconds; annealing was done at the respective temperature for each primer $\left(60.4,61.0,61.59\right.$ and $\left.61.53^{\circ} \mathrm{C}\right)$ for 30 seconds and 36 cycles; and extension at $72{ }^{\circ} \mathrm{C}$ for 45 seconds. The final extension was at $72{ }^{\circ} \mathrm{C}$ for 5 minutes and then a hold temperature at $4^{\circ} \mathrm{C}$. Five microlitres of the PCR product was electrophoresed in 2\% agarose gel (Bioline) containing $5 \mu \mathrm{l}$ of $10 \mathrm{mg} / \mathrm{ml}$ ethidium bromide at $100 \mathrm{~V}$ for 45 minutes. A $1 \mathrm{~kb}$ plus DNA marker was used as molecular size marker. DNA amplifications were examined under ultraviolet (U.V) transilluminator and results documented (Paton and Paton, 1998; Moyo et al., 2007; Bitrus et al., 2011; Ding et al., 2011; Jalil et al., 2011).

Sequencing of the 16SrRNA gene was carried out with a sequencing machine (Applied Biosystems, HITACHI 3130 × 1 Genetic Analyzer). The sequences were analyzed with the Finch TV and BIOEDIT (version 7.2.5.0) software after which the basic local alignment search tool (BLAST) was carried out on the National Centre for Biotechnology Information (NCBI) website (www.ncbi.nlm.nih.gov) to identify the organism.

\section{RESULTS AND DISCUSSION}


Table 3.1 : Isolation frequency of E. coli O157:H7 from water sources of Ikara LGA

\begin{tabular}{ll}
\hline Water source (n) & E. coli O157:H7 isolated $\mathbf{n} \mathbf{~ ( \% )}$ \\
\hline Borehole (24) & $0(0)$ \\
Pipe-borne water(5) & $0(0)$ \\
Sachet water (19) & $0(0)$ \\
Well water (29) & $2(6.9)$ \\
Stream (3) & $1(33.3)$ \\
\hline Total- $\mathbf{8 0}$ & $\mathbf{3 ( 3 . 7 5 )}$ \\
\hline
\end{tabular}

Table 3.2: Sources of E. coli $\mathrm{O} 157: \mathrm{H} 7$ possessing virulence genes

\begin{tabular}{lllll}
\hline $\begin{array}{l}\text { Isolate } \\
\text { s/no }\end{array}$ & Identity & Source & $\begin{array}{l}\text { Virulence } \\
\text { genes } \\
\text { detected }\end{array}$ & $\begin{array}{l}\text { GenBank } \\
\text { accession } \\
\text { number }\end{array}$ \\
\hline 196 & E. coli O157:H7 & Well water & Stx2, bly $A$ & KX602654 \\
198 & E. coli O157:H7 & Well water & $\begin{array}{l}\text { Stx2, bly } A \text {, eaeA } \\
\text { KX602653 }\end{array}$ & KX602652 \\
\hline
\end{tabular}

The $3.75 \%$ isolation rate of E. coli O157:H7 though low, is a very significant finding because of the pathogenicity of this organism (Table 3.1). The WHO states that E. coli should not be found at all in drinking water, therefore, we can safely conclude that by this standard, the affected water sources are unfit for drinking. Most of the wells in the study area had previously been observed to lack covers and casings (Olukosi et al., 2008), so this could be a reason why the wells could easily get contaminated from run-offs during rainfall. Also, being a semi-rural area, there was the presence of animals such as sheep, goats and cows grazing around. A previous study on well water of Zaria metropolis reported a $2.5 \%$ isolation rate of the organism (Olukosi et al., 2008).

The genes that were observed to be present in the isolates are a sign that they are most likely pathogenic (Barkocy-Gallagher et al., 2004). The st $x 1$ gene was not observed in any of the isolates, while the st $x 2$ gene was observed in all three (Table 3.2). The progression of disease caused by E.coli O157:H7 in humans is largely dependent on a number of bacterial virulence factors including st $x$ 1, stx2, haemolysin $(b l y A)$, and intimin (eae $A)$ genes among others (Wang et al., 2008), with stx2 being the most important of them all (Kawano et al., 2008). In human, Shiga toxins are the major virulence factors of STEC responsible for haemorrhagic colitis (HC) and haemolytic uremic syndrome (HUS). Within the human disease- associated strains, those producing stx2 appear to be more commonly responsible for serious complications. Previous studies have shown that stx 1 genotype is one of the important factors of clinical outcome of E. coli O157:H7 infection and that pathogenicity for humans was higher in the stx2 genotype strains (Kargar and Homayoon, 2015). It is also possible that the stx 1 gene was lost during culturing of the isolates (Mazaheri et al., 2005).

The intimin gene (eae $A$ ) was observed in just one E. coli $\mathrm{O} 157: \mathrm{H} 7$ isolate (Table 3.2). This gene has been shown to be responsible for the organism's intimate attachment to epithelial cells of the intestine, giving rise to attaching and effacing lesions in the intestinal mucosa. However, it has been observed from other studies that many human STEC isolates including those from patients with haemolytic uraemic syndrome and haemorrhagic colitis did not contain eae $A$. This indicates that this gene might not be essential for human infection (Blanco et al., 2006).

The enterohemolysin (Ehly), also called enterohemorrhagic E. coli haemolysin (EHECHlyA), encoded by the bly gene is another virulence factor of E. coli. This gene has been shown to be responsible for the production of enterohemolysin which gives the organism the ability to cause severe disease as it has been observed in isolates that caused hemolytic uraemic 
syndrome (Paton and Paton, 1998; Pradel et al., 2001; Grauke et al., 2002).

\section{CONCLUSION}

The occurrence of E. coli O157:H7 carrying virulence genes is an indication that the water sources from which they were isolated are unfit for human consumption except with further treatment. More focus has to be given to drinking water in Ikara, Kaduna state of Nigeria so as to prevent health hazards of waterborne diseases. The populace could also be educated on the need to drink water from safe sources, or at least boil water before drinking. The government also needs to provide potable sources of drinking water for the general public.

\section{REFERENCES}

Barkocy-Gallagher, G.A., Arthur, T.M., RiveraBetancourt, M., Nou, X., Shackelford,S.D., Wheeler,T.L. and Koohmaraie, M. 2004. Characterization of $\mathrm{O} 157: \mathrm{H} 7$ and other Escherichia coli isolates recovered from cattle hides, faeces, and carcasses. Journal of Food Protection 67(5):993-998.

Bitrus, Y., Duru, B.N. and Ali, U.D. 2011. Public health risk of O157 and Non-O157 Shiga toxin producing Escherichia coli strains in a semi-urban environment in Nigeria. African Journal of Microbiology Research 5(31):5636-5643.

Blanco, M., Blanco, J.E., Dahbi, G., Mora, A., Alonso, M.P., Varela, G., Gadea, M.P., Schelotto, F., Gonza' lez, E.A. and Blanco, J. 2006. Typing of intimin (eae) genes from enteropathogenic Escherichia coli (EPEC) isolated from children with diarrhoea in Montevideo, Uruguay: Identification of two novel in t i m in variants $(\mu \mathrm{B}$ and $\xi \mathrm{R} / \beta 2 \mathrm{~B})$. Journal of Medical Microbiology 55(9):1165-1174.

Ding, H., Huang, L.. Mao, X. and Zou, Q. 2011. Characterization of stx 2 and its variants in Escherichia coli O157:H7 isolated from patients and animals. African Journal of Biotechnology 10(15):2991-2998.

Franiczek, R., Dolna, I., Krayzanowska, B., Szufnarowski, K., Kowalska-Krochmal, B. and ZieliA,,ska, M. 2006. Conjugative transfer frequency of resistance genes from ESBL- producing Enterobacteriaceae strains isolated from patients hospitalized in pediatric wards (in Polish). Medycyna doAwiadczalna $i$ mikrobiologia. 58(1):41-51.

Cheesbrough, M. 2006. District Laboratory Manual For Tropical Countries, part 2. Cambridge University press, U.K., pp 38, 63-70.

Grauke, L.J., Kudva, I.T., Yoon, J.W., Hunt, C.W., William, C.I., and Hovdje, C.J. 2002. Gastrointestinal tract location of Escherichia coli O157:H7 in ruminants. Applied and Environmental Microbiology 68:2269-2277.

Jalil, K., Vadood, R. and Abolfazl, B. 2011. Direct detection of Escherichia coli O157 and its major virulence factor genes in animal faeces at slaughter using multiplex polymerase chain reaction (PCR). African Journal of Microbiology Research 5(14):1763-1767.

Kaper, J.B., Nataro, J.P. and Mobley, H.L.T. 2004. Pathogenic Escherichia coli. Nature Reviews 2(2):123-140.

Kawano, K., Okada, M., Haga, T., Maeda, K. and Goto, Y. 2008. Relationship between pathogenicity for humans and stx genotype in Shiga toxin-producing Escherichia coli serotype O157. European Journal of Clinical Microbiology and Infectious Diseases 27(3):227-232.

LeJejune, J.T., Besser T. E., Rice D. H., and Hancock D. D. 2001. Methods for the isolation of water-borne Escherichia coli 0157:H7. Letters in Applied Microbiology. 32: 316-320.

Mazhaheri, N. F. R., Behzadian, N. G., Zahraei, S. T., Atash, P. N. 2005. Evaluation of ehxA, stx1, and stx2 Virulence Gene Prevalence in Cattle Escherichia coli Isolates by Multiplex PCR Short Communication. Archives of Razi Institute 60:55-66.

Mora, A., Blanco, M., Blanco, J.E., Dahbi, G., lpez, C., Justel, P. 2007. Serotypes, virulence genes and intimin types of shiga toxin (verocytotoxin)- producing Escherichia coli isolates from minced beef in Lugo (Spain) from 1995 through 2003. BMC Microbiology, 7:1-9.

Moyo, S.J., Maselle, S.Y., Matee, M.I., Langeland, N. and Mylvaganam, H. 2007. 
Identification of diarrheagenic Escherichia coli isolated from infants and children in Dar es Salaam, Tanzania. $B M C$ (BioMedCentral) Infectious Diseases 7(1):92.

National Population Commission (NPC) (2010). Federal Republic of Nigeria 2006 Population and Housing Census, Priority Table Volume III, Population Distribution by Sex, State, LGA \& Senatorial District, available at www.population.gov.ng/files/nationafinal.pd f.

Olukosi, O.M., Ameh, J.B and Abdullahi, I.O. 2008. The prevalence of Escherichia Coli O157:H7 in well water source in Zaria metropolis, Kaduna state, Nigeria. Biological and Environmental Sciences Journal for the Tropics 5(4):134-138.

Paton, J. C. and Paton, A. W. 1998. Pathogenesis and diagnosis of shiga-toxin producing Escherichia coli infections. Clinical Microbiology Reviews 11:450-479.

Pradel, N., Boukhors, K., Bertin, Y., Forestier, C., Martin, C. and Livrelli, V. 2001. Heterogeneity of Shiga toxin-producing Escherichia coli strains isolated from hemolytic-uremic syndrome patients, cattle, and food samples in central France. Applied Environmental Microbiology 67:2460-
2468.

Renter, D.G., Sargeant, J.M., Oberst, R.D. and Samadpour, M. 2003. Diversity, Frequency, and Persistence of Escherichia coli O157 Strains from Range Cattle Environments. Applied and Environmental Microbiology 69(1): 542-547.

Tijjani, M.B., Umoh, V.J., and Jatau, J.D. (2006). Microbiological risks associated with urban livestock production in Kaduna, Nigeria. An M.Sc Research Thesis, Department of Microbiology, Ahmadu Bello University, Zaria. Pp 4

UNICEF 2008. UNICEF Handbook on Water Quality (C) United Nations Children's Fund (UNICEF), New York, PP 1.

Wang, H., Mao, X., Ding, H., Zou, Q., and Peng, X. 2008. Epidemiological survey on Escherichia coli O157 in Chongqing and Three-Gorge Reservoir Areas of China. Veterinary Research Communications, 32(6):449-461.

WHO and UNICEF 2010. Rapid assessment of drinking-water quality in the Federal Republic of Nigeria: country report of the pilot project implementation in 20042005 / WHO Press, World Health Organization, 20 Avenue Appia, 1211 Geneva 27, Switzerland. Page viii. 